\title{
Population genetics of sugar kelp in the Northwest Atlantic region using genome-wide markers
}

Authors: Xiaowei Mao ${ }^{1,2,3} \dagger$, Simona Augyte ${ }^{4,5} \dagger$, Mao Huang ${ }^{3}$, Matthew P. Hare ${ }^{6}$, David Bailey $^{7}$, Schery Umanzor ${ }^{4}$, Michael Marty-Rivera ${ }^{4}$, Kelly R Robbins ${ }^{3}$, Charles Yarish ${ }^{4}$, Scott Lindell $^{7}$, Jean-Luc Jannink ${ }^{3,8}$

${ }^{1}$ Key Laboratory of Vertebrate Evolution and Human Origins, Institute of Vertebrate Paleontology and Paleoanthropology, Chinese Academy of Sciences, Beijing, China; ${ }^{2}$ CAS Center for Excellence in Life and Paleoenvironment, Beijing, China; ${ }^{3}$ Section on Plant Breeding and Genetics, School of Integrative Plant Sciences, Cornell University, Ithaca, NY, USA; ${ }^{4}$ Department of Ecology \& Evolutionary Biology, University of Connecticut, Stamford CT, USA; ${ }^{5}$ Symbrosia Inc., Kailua-Kona, HI; ${ }^{6}$ Department of Natural Resources, Cornell University, Ithaca, NY, USA; ${ }^{7}$ Applied Ocean Physics and Engineering, Woods Hole Oceanographic Institution, Woods Hole, MA, USA; ${ }^{8}$ United States Department of Agriculture - Agriculture Research Service, Ithaca, NY, USA

$\dagger$ These authors contributed equally to this work. The current affiliation for XM is 1 and 2; and for $\mathrm{SA}$ is 5.

*corresponding author; mh865@cornell.edu 


\begin{abstract}
An assessment of genetic diversity of marine populations is critical not only for the understanding and preservation of natural biodiversity but also for its economic potential. As commercial demand rises for marine resources, it is critical to generate baseline information for monitoring wild populations. Furthermore, anthropogenic stressors on the coastal environment, such as warming sea surface temperatures and overharvesting of wild populations, are leading to the destruction of keystone marine species such as kelps. In this study, we conducted a fine-scale genetic analysis using genome-wide high-density markers on Northwest Atlantic sugar kelp species, Saccharina latissima and putative species, Saccharina angustissima. The population structure for a total of 149 samples from the Gulf of Maine (GOM) and Southern New England (SNE) was investigated using AMOVA, Fst, admixture, and PCoA. Genome-wide association analyses were conducted for six morphological traits, and the extended Lewontin and Krakauer (FLK) test was used to detect selection signatures. Our results indicate that the GOM region is moderately more heterogeneous than SNE. While admixture was observed between regions, these results confirm that Cape Cod acts as a biogeographic barrier for sugar kelp gene flow. We detected one significant SNP $\left(\mathrm{P}\right.$-value=2.03 $\times 10^{-7}$ ) associated with stipe length, and 243 SNPs with higher-than-neutral differentiation. The findings of this study provide fundamental knowledge on sugar kelp population genetics for future monitoring, managing and potentially restoring wild populations, as well as assisting in selective breeding to improve desirable traits for cultivation and bioenergy production.
\end{abstract}

\title{
Introduction
}


Brown macroalgae in the order Laminariales (Phaeophyceae), or kelp, are keystone species in the near-shore temperate marine environment. As primary producers, they are at the base of many food webs and provide numerous ecosystem functions including detrital production, wave attenuation, habitat modification, and carbon sequestration (Dayton 1985; Bartsch et al., 2008; Falkenberg et al., 2012; Efird and Konar 2014; Trebilco et al., 2015). For humans around the globe, kelp has long provided both a food source and bioextracts with various applications (Bartch et al., 2008).

Besides their important ecological roles and the well-established kelp cultivation practices in coastal Asian countries, there is growing interest in macroalgal cultivation in Europe, South America, and throughout the USA (Augyte et al., 2017; Buschmann et al., 2017; Campbell et al., 2019; Grebe et al., 2019; Kim et al., 2019; Geocke et al., 2020). Specifically, there are efforts to selectively breed kelp for large-scale food and bioenergy production (Bjerregaard et al., 2016; Hwang et al., 2019; Geocke et al., 2020) and increasing demand for germplasm banking to support future cultivation as well as restoration research (Barrento et al., 2016; Wade et al., 2020). To assist in the establishment of this nascent industry, an understanding of genetic variation across wild kelp populations is essential. Intensive selection pressure during the marine crop domestication process leads to favoring certain phenotypic traits (Zhang et al., 2017). These mechanisms may promote adaptive divergence between cultivated seaweeds and wild populations and it is, therefore, critical to have an understanding of wild phenotypic traits as they undergo domestication. This will foster future breeding and cultivation efforts in a sustainable and informed manner for managers, conservation groups, researchers, and industry.

Although kelp are key both ecologically and economically worldwide, the evolutionary history of kelp species is not entirely known (Bolton 2010; Starko et al., 2019). Limited research exists 
on the genetic and phenotypic structure of kelp within species, despite broad range distributions and likely regional adaptation (Valero et al., 2011). Existing S. latissima populations colonized the eastern and western North Atlantic coasts post-glacially from a north Pacific source via the oceanographic flow through the Arctic (Neiva et al., 2018). New evidence suggests that kelp have radiated at a constant rate, but members of the clade containing Saccharina show an additional rate increase (Starko et al. 2019).

Genetic population structure depends on the mode of reproduction and dispersal ability (Valero et al., 2011), and therefore provides insights about gene flow among populations (Durrant et al., 2018). In the marine environment, where direct observation of dispersal can be challenging, genetic tools provide an opportunity to better recognize patterns and scales of population connectivity (Valero et al., 2011). Nearshore kelp cultivation efforts have raised concerns by resource managers of the potential of farm cultivars to introgress with wild populations. However, for kelp species like S. latissima, dispersal distances of meiospores and gametes are generally short, usually not exceeding a few meters (Paine 1979; Hoffman and Santelices 1991). This was demonstrated by Zhang et al. (2017) where genetic structure and relatedness were evaluated in 8 wild populations and 17 farmed Saccharina japonica and they observed that wild populations have not been significantly impacted by gene flow from cultivated populations.

In the Northwest Atlantic, several small-scale studies have investigated the genetic population structure of S. latissima within small geographic ranges. A previous study in the Gulf of Maine, (GOM) reported slight genetic differentiation between five S. latissima populations spanning 225 km (Breton et al., 2018). Augyte et al., (2017) also found a slight distinction between the sugar kelp population at one site in Long Island Sound (LIS) as compared to three populations tested in the GOM. However, these and other population-level genetic studies of kelp may have been 
limited by variation levels in amplified fragment length polymorphisms (Vos et al., 1995) and microsatellites (Neiva et al., 2018; Richard et al., 2008; Nielsen et al., 2016; Paulino et al., 2016). Improvements in the speed, cost, and accuracy of next-generation sequencing (NGS) data can now provide better resolution to kelp genetics studies. In addition to NGS, reduced representational sequencing such as Genotyping by Sequencing (GBS) (Elshire et al., 2011) and Diversity Arrays Technology (DArT) (Jaccoud et al., 2001) have additional advantages, including reducing the genome complexity, avoiding inherent ascertainment bias in fixed SNP arrays, and decreasing sequencing costs. The high density of SNPs from these methods provides a finer understanding of the evolutionary processes shaping genetic diversity and, in some cases may be informative about genes affecting complex traits in wild populations.

Our study focused on Saccharina latissima, sugar kelp, which has a circumboreal distribution. In the Northwest Atlantic, its southern distributional limit is in Long Island Sound (LIS), with one disjunct historic population at an offshore site in New Jersey (Egan and Yarish 1988). Long Island Sound $\left(41^{\circ} \mathrm{N}, 72-73^{\circ} \mathrm{W}\right)$ has a coastline of roughly $176 \mathrm{~km}$ and ranges from New York City in the west to Fisher's Island in the east (Mathieson and Dawes 1988). To the north of LIS, separated by Cape Cod, is the Gulf of Maine (GOM) where a dominant coastal current flows southwestward (Pappalardo et al., 2015). This direction in water flow may contribute to sugar kelp gene flow moving southward via meiospore or rafting transport. The GOM is also home to an endemic kelp, Saccharina angustissima, closely related to S. latissima but with a distinctive strap-like morphology, found only within an eight nautical mile radius on intertidal ledges and islands exposed to heavy surf (Mathieson et al., 2008; Augyte et al., 2017; 2018).

The objectives of this study were twofold: 1) to explore the finer population structure of sugar kelp (S. latissima and S. angustissima) in the Northwest Atlantic and the admixture between 
regions separated by Cape Cod and 2) to test for associations between genetic variation and phenotypic trait variation. This study is fundamental to understanding the genetic diversity of sugar kelp in the context of species adaptation to environmental stressors, especially in the face of changing climate and warming oceans (Reusch et al., 2005). Furthermore, our work has the potential to inform recommendations for protecting coastal marine ecosystems and guide future kelp breeding and cultivation efforts by building a baseline of knowledge about kelp population diversity and connectivity.

\section{Materials and Methods}

\section{Sample collection and phenotypic analysis}

A total of 189 wild kelp samples were collected by SCUBA diving at 15 locations (Fig. 1) throughout the Northwest Atlantic conducted during April - June of 2018. Among these samples, we recorded six morphological traits on 165 samples from 15 locations (Table 1). Of these, care was taken to identify and only use reproductive blades, and thus it was assumed that most of the blades were at full maturity. The six traits were blade length, blade width at $10 \mathrm{~cm}$, blade width at the widest portion of the blade, blade thickness, stipe length, and stipe diameter. Collection locations were selected based on existing kelp beds and the ease of access (Table 1). Among these 15 locations, S. angustissima was found only at one location (Giant's Staircase). The population sampled (defined as all 15 locations) was divided into two regions separated by Cape Cod, with GOM to the north of Cape Cod, and Southern New England (SNE) to the south. Radar plots of the mean and standard deviation of morphological traits were made to visualize diversity. Furthermore, pairwise correlations of the six traits were estimated using the cor() 
function in R (method = "pearson", option = "na.or.complete"). The correlation was considered statistically significant when P-value $<0.05$.

\section{DNA extraction and genotyping}

Of the 189 collected samples, 149 kelp samples from both GOM and SNE for 15 locations were genotyped desiccate. After transport to UCONN Stamford, Marine Biotechnology Laboratory, samples were ground up with mortar and pestle using liquid nitrogen. Weights of $5 \mathrm{mg}$ per sample were measured and sent to DArT Ltd (Diversity Arrays Technology, Canberra, Australia) sequencing facility for DNA isolation and genotyping. Genomic DNA was extracted according to the modified CTAB protocol (Doyle and Doyle, 1990). Then DNA quality and quantity were evaluated with a DS-11FX series spectrophotometer (Denovix, Wilmington, DE, USA), followed by running agarose $(1.2 \%)$ gel electrophoresis. Sugar kelp genotyping was carried out in two steps: First, reduced genomic representations were generated following the procedures described by Kilian et al (2012). This procedure included the digestion of DNA samples using a rare cutting enzyme PstI and secondary frequently cutting restriction endonucleases (RE), ligation with site-specific adapters, and amplification of adapter-ligated fragments. Second, nextgeneration sequencing technology was applied to detect SNPs and silicoDArT markers using HiSeq2000 (Illumina, USA). The sequence data were analyzed using DarTsoft14 (an automated genotypic data analysis program) and DArTdb (a laboratory management system). Two technical replicates of each DNA sample were genotyped to guarantee the reproducibility of the sequencing. The detailed procedure can be found in Kilian et al., (2012). 


\section{Quality control for SNPs}

A total of 20,242 SNPs were identified and five steps of quality control were applied to the SNP data: 1. Removal of sequence tags with more than one SNP; 2. Removal of SNPs with call rate (proportion with non-missing samples) less than 95\%; 3. Removal of samples with call rate (proportion with non-missing SNPs) less than 90\%; 4. Removal of SNPs with minor allele frequency $(\mathrm{MAF})<0.05$; 5. Removal of SNPs severely departing from Hardy-WeinbergEquilibrium $(\mathrm{P}$-value $<0.01$ ) in more than $1 / 4$ of all collection sites. After the quality control, a total of 149 samples and 4,905 SNPs were retained.

\section{Sequence diversity and population structure}

The sequence diversity for samples within each location was assessed by summary statistics of average expected heterozygosity $\left(\mathrm{H}_{\mathrm{E}}\right)$, average observed heterozygosity $\left(\mathrm{H}_{\mathrm{O}}\right)$, and inbreeding coefficient ( $\mathrm{F}_{\mathrm{IS}}$ ), using the R package hierfstat (Yang 2006).

Population structure was assessed through analysis of molecular variance (AMOVA), pairwise $\mathrm{F}_{\mathrm{ST}}$, Principle Coordinate Analysis (PCoA) and admixture analysis. First, the presence of a hierarchical population structure was investigated using the AMOVA (Excoffier et al., 1992) implemented in the R package poppr (Kamvar et al., 2015). In AMOVA, hierarchical variance components of GOM and SNE were estimated both combined and separately, where $S$. angustissima and S. latissima were analyzed together, due to their similarities inferred from PCoA. Second, pairwise relationships among all locations were investigated by calculating pairwise $\mathrm{F}_{\mathrm{ST}}$ using the R package StAMPP (Pembelton et al., 2013). The AMOVA and pairwise $\mathrm{F}_{\mathrm{ST}}$ rely on geographical assignments, estimating genetic differentiation among different locations. The underlying population structure was further investigated through PCoA 
implemented in the R package Adegenet (Jombart 2008). The PCoA is a model-free approach, which is commonly used to find hidden structure among samples as the population is not preassigned. Admixture analysis was done in R using the conStruct package (Bradburd et al., 2018). Similar to other population structure analyses, this model assumes a number K of distinct ancestral populations, called "layers". Distinct from other models, conStruct fits isolation by distance (IBD) within layers. Bradburd et al. (2018) showed this model better captures the true subpopulation structure when compared to conventional non-spatial admixture modeling. Models with different values of $\mathrm{K}$ are fit and a "best model" can be chosen either based on its crossvalidation prediction of covariances in allelic frequencies across samples or based on the contribution of layers to explaining allelic frequency covariance. Due to computational intensity in conducting the cross-validation approach, we used the latter approach. The model was initially fit using values of $K=1$ to $K=10$ for the full set of samples and $K=1$ to $K=6$ for the GOM samples using a smaller number of iterations $(8,000)$. Based on these results, we reduced the values of $\mathrm{K}$ to 1 to 6 for the full set and 1 to 4 for the GOM samples using a larger number of iterations (50,000 MCMC iterations with a burn-in of 500 iterations that were discarded). The final selection of $\mathrm{K}$ was chosen based on: the minimum contribution for a layer to be included was $1 \%$ of the total covariance (Supplemental Fig. 1). This resulted in $\mathrm{K}=3$ for all samples tested, and $\mathrm{K}=2$ for just the GOM samples.

\section{Isolation by distance}

The extent of IBD (Wright 1931), which assumes that populations that are geographically closer tend to be more closely related genetically, was also estimated for our samples using a Mantel test implemented in R package VEGAN. In the Mantel test, genetic distance was represented by 
$\mathrm{F}_{\mathrm{ST}} /\left(1-\mathrm{F}_{\mathrm{ST}}\right)$, and geographical distance was calculated as "the crow flies" (straight line) between our collection sites. The Mantel test was run for GOM and SNE separately with 999 permutations to assess the significance of the correlation between genetic and geographic distance.

\section{Genome-wide association analyses of morphological traits}

A genome-wide association study (GWAS) was conducted on six traits using the 4,905 SNP markers and 98 GOM plus 27 SNE samples (a common set out of the 149 genotyped and 165 phenotyped samples). Due to the strong subpopulation structure in this data set and to account for sampling location variation, the sampling location (15 locations) was included as a categorical fixed effect in the GWAS model using the R package GAPIT (Lipka et al., 2012). The kinship matrix was estimated using $r r B L U P$ package (Endelman, 2011) with the A.mat() function and included in the GWAS model. The mixed linear model was as follows:

$$
\mathbf{y}=\mathbf{1} \mu+\mathbf{X b}+\mathbf{s} \alpha+\mathbf{Z} \mathbf{u}+\mathbf{e}
$$

where $\mathbf{y}$ was a vector of the response variable for one of the morphological traits, $\mathbf{1}$ was a vector of ones, $\mu$ was the common population mean, $\mathbf{b}$ was the vector of location effects, $\mathbf{X}$ was an incidence matrix relating location to each individual, $\alpha$ was the additive allele substitution effect of the SNP, and $\mathbf{s}$ was the design matrix for SNPs. Elements of the vector $\mathbf{s}$ were allele dosages (0 to 2) for one randomly chosen allele at each locus. $\mathbf{Z}$ was an incidence matrix relating the vector of additive polygenic values $\mathbf{u}$ to individuals, and $\mathbf{e}$ was the error term. The values $\mathbf{u}$ and $\mathbf{e}$ were assumed to follow multivariate normal distributions, $\mathbf{u} \sim\left(\mathbf{0}, \sigma_{\square}^{2} \square\right)$ and $\mathbf{e} \sim\left(\mathbf{0}, \sigma_{\square}^{2} \square\right)$ respectively, where $G$ was the genomic covariance matrix estimated by GAPIT using the kinship matrix. $I$ was an identity matrix, $\sigma_{\square}^{2}$ was the genetic variance, and $\sigma_{\square}^{2}$ was the residual variance. 
To correct for the multiple testing, a Bonferroni correction was used. The resulting significance level threshold was $0.05 / 4,905=1.02 \times 10^{-5}$. SNPs with a P-value below this threshold were significantly associated with morphological traits.

\section{Detection of selection signatures}

The FLK test (Bonhomme et al., 2010) was used to test for signatures of selection. This test can identify SNPs with especially high differentiation among populations, so-called outliers relative to the neutral background, while accounting for the hierarchical structure among populations. We applied the FLK test to 149 genotyped samples from 15 locations which included both GOM and SNE samples where GOM included both S. latissima and closely related S. angustissima. There were five steps for running the FLK analysis with detailed information described by Bonhomme et al. (2010): 1. Compute Reynolds' genetic distance from SNP data; 2. Build rooted Neighborjoining tree using the $\mathrm{R}$ package APE (Paradis et al., 2004); 3. Compute population kinship matrix from Neighbor-joining tree; 4. Compute FLK test statistic; 5. Simulate empirical distribution of FLK test statistic under the null hypothesis of neutral evolution with 50,000 replicate and return the empirical quantiles of the null distribution. FLK test statistics above 0.995 quantiles were considered to be significant. This procedure was applied to the 4,905 SNPs for all populations.

\section{Results}

\section{Phenotypes of collected samples}

Large morphological variation was observed across locations for the collected samples (Fig. 2). Blade lengths ranged from $84.5 \pm 37.5 \mathrm{~cm}$ for Pine Island to $227.4 \pm 22.9 \mathrm{~cm}$ for Mount Desert Rock; blade widths at $10 \mathrm{~cm}$ ranged from $2.2 \pm 0.3 \mathrm{~cm}$ for Giant Staircase to $24.6 \pm 1.6 \mathrm{~cm}$ for 
Downeast Institute; blade widths at the widest ranged from $3.4 \pm 0.3 \mathrm{~mm}$ for Giant Staircase to $41.4 \pm 2.3 \mathrm{~mm}$ for Orr's Island; stipe diameter ranged from $2.17 \pm 0.61 \mathrm{~mm}$ for Giant Staircase to $14.43 \pm 2.17 \mathrm{~mm}$ for Downeast Institute; stipe lengths ranged from $4.8 \pm 0.6 \mathrm{~cm}$ for Giant Staircase to $122.7 \pm 18.9 \mathrm{~cm}$ for Lubec Light; blade thickness ranged from $0.8 \pm 0.00 \mathrm{~mm}$ for Pine Island to $2.28 \pm 0.14 \mathrm{~mm}$ for Downeast Institute. Most of the pairwise correlations were positive except for the correlation between blade width at $10 \mathrm{~cm}$ and blade length which was 0.05 but not significantly different from zero (Fig. 3). Among all positive correlations, stipe length was most highly correlated with stipe diameter $(0.85)$, and blade width at the widest portion was most highly correlated with blade width at $10 \mathrm{~cm}(0.80)$.

\section{Sequence diversity}

Most locations had a slightly negative inbreeding coefficient ( $F_{I S}$ ) (Table 1). Observed heterozygosity (Ho) values ranged from 0.27 for Giant's Staircase to 0.322 for Newcastle. Overall, expected and observed heterozygosity was similar, suggesting random mating in all sampled locations. Lubec Dock had the most negative $F_{\text {IS }}$ and Pine Island had the most positive F IS among all locations.

\section{Population structure}

The AMOVA results indicate that roughly half of the total variation exists within locations (56.4\%), while the least variation exists among locations within each region $(14.4 \%$, Table 2$)$, similar to what has been reported by Geocke et al., (2020). Variation among locations was higher in GOM (23.0\% of the total variance) than among locations in SNE (6.8\%, Table 2). Populations in SNE were more genetically homogenous than populations in GOM: the average pairwise $\mathrm{F}_{\mathrm{ST}}$ among SNE locations was 0.03 , as compared to 0.13 among GOM locations. More revealing was 
that pairwise $\mathrm{F}_{\mathrm{ST}}$ showed that GOM was distantly related to $\mathrm{SNE}\left(\mathrm{F}_{\mathrm{ST}}>0.25\right.$, Fig. 4 ,

Supplemental Table 1). The PCoA revealed two major clusters, dividing samples into GOM and

SNE regions (Fig. 5). The admixture analysis using conStruct revealed three underlying ancestral

populations for all our 149 samples (Fig. 6). There was a clear difference between GOM and

SNE, corresponding well to the pairwise $\mathrm{F}_{\mathrm{ST}}$ analysis and supported by the PCoA results (Fig. 5).

Yet samples from SNE share some ancestry with samples from GOM.

\section{Isolation by distance}

Testing IBD for each region separately, the Mantel tests (Fig. 7) showed a moderately positive correlation for GOM $(r=0.47, \mathrm{P}$-value $=0.002)$ and a strong positive correlation for $\mathrm{SNE}(\mathrm{r}=$ 0.94, P-value $=0.125)$. The strong IBD was not significant for SNE due to the small number of populations $(n=4)$.

\section{Genome-wide association analyses}

Only one SNP (37855763-68-T/C, SNP ID assigned by DArT) was significantly associated with a trait (stipe length $\mathrm{P}$-value $=2.03 \times 10^{-7}$ ), with a minor allele frequency of 0.07 overall. The sequence containing SNP data is provided in Supplement Table 2.

\section{Detection of selection signatures}

The FLK test detected potentially non-neutral outlier loci, which could have resulted from local adaptation involving linked sites. FLK statistics above the 0.995 quantiles were considered significant. A total of 249 SNPs were identified. The SNP with the highest FLK statistic (162.61) was 37850355-52-C/T. The heterozygosity of the SNP was 0.13 .

\section{Discussion}


In this study, we investigated the genetic population structure of wild sugar kelp (Saccharina sp.) populations in Northwest Atlantic using genome-wide SNP data. This structure is driven by mutation, drift, selection, and migration. The molecular methods used here can be applied to a variety of marine organisms to identify fine-scale population structure in nearshore coastal systems. Furthermore, we evaluated the phenotypic variation among wild samples. In general, the phenotypic patterns varied from one location to another which is expected given the variation in environmental conditions throughout the sampling region and the plasticity of kelp in response (Bartsch et al., 2008).

\section{Population structure}

A clear population structure was observed among natural samples collected from the Northwest Atlantic. The sugar kelp from GOM and SNE formed three sub-populations, as demonstrated by analyses of pairwise $\mathrm{F}_{\mathrm{ST}}$, PCoA, and admixture. The major genetic distinction between GOM and SNE suggests that Cape Cod acts as a biogeographic barrier for sugar kelp gene flow. Previous studies on larval transport reveal that species boundaries exist at Cape Cod largely set by the interaction of currents, depth distribution, and in the case of larvae, their pelagic duration (Pappalardo et al., 2015).

Overall, populations in the GOM showed three times more structure among locations than those found in SNE based on hierarchical AMOVA and pairwise $F_{S T}$ (Table 2, Fig.4). The difference in the genetic population structure between the GOM and SNE was also qualitatively confirmed by PCoA (Fig. 5). The differentiation observed between S. angustissima (at Giant's Staircase) and S. latissima was similar to that of S. latissima among locations (Fig. 5). The largest F $_{\mathrm{ST}}$ between $S$. angustissima and S. latissima, 0.29, was no larger than that of S. latissima samples 
between GOM and SNE (largest $F_{S T}$ 0.32). Moreover, manipulative crosses between gametophytes obtained from S. angustissima and S. latissima can produce fertile hybrids (Umanzor et al., In Prep), indicating a lack of intrinsic reproductive isolating mechanisms. Nonetheless, previous ecological and molecular studies suggested divergence between these kelp forms, including habitat, morphology, and several organellar markers (Augyte et al., 2018). Common garden experiments further suggest a genetic basis driving the unique morphology of $S$. angustissima (Augyte at el., 2017; 2018).

The difference between the population structure of GOM and SNE might also be due to postglacial migration. Biogeographic reconstruction suggests the early expansion and diversification of complex kelp started in the northeast Pacific with dispersal and colonization to other regions via oceanographic flow through the Bering Strait and Arctic (Wares et al., 2001; Neiva et al., 2018; Starko et al., 2019). Divergence of western and eastern Atlantic populations predates the Last Glacial Maximum (Neiva et al., 2018) when an ice sheet extended onto the continental shelf and reached into the western Atlantic as far south as Long Island, New York (Maggs et al., 2008). Arctic populations with genetic affinities to the North Pacific and western Atlantic sugar kelp populations currently are hybridizing in parts of the Arctic, which may be typical of previous interglacial periods (Neiva et al., 2018). The southern range edge populations (SNE) analyzed here, in contrast, may remain more isolated and persist across climatic shifts or glacial vicariance events (Neiva et al., 2018).

\section{Candidate SNPs for morphology and selection signature}

To our knowledge, no candidate genes have been reported for morphological traits in sugar kelp. In a closely related species Saccharina japonica, candidate genes have been reported for blade 
length and blade width (Wang et al., 2018). We found one SNP, 37855763-68-T/C, significantly associated with stipe length. More SNPs might have been discovered associated with other traits with a larger sample size. In the future, more samples should be collected for detecting the causal loci affecting sugar kelp morphology to better understand the genetic architecture of traits of economic interest.

There was no overlap between SNPs detected from GWAS and the FLK test because these tests exploit different signals in the data. As implemented here, the association analysis identified an SNP causing variation within locations, whereas the FLK test identified SNPs exceptionally divergent between locations. In addition, the association study adopted a stringent Bonferroni correction to eliminate false positives, resulting in a small set of significant SNPs. Finally, GWAS is a powerful statistical method for linking genotype to phenotype, but in the context of genomic variation caused by ongoing evolutionary forces such as selection, it is hampered by confounding selective pressures such as drift causing population structure (e.g., Liu et al., 2016).

\section{Genetic diversity within locations}

Zhang et al (2015) reported using high-density SNP markers to assess kelp genetics for Saccharina japonica. To the best of our knowledge, our study is the first genetic study for $S$. latissima and putative species S. angustissima in the Northwest Atlantic region using genomewide SNP data. Previously, genetic diversity in eastern Maine was assessed using 12 microsatellite markers, and samples from five intertidal locations (i.e., Penobscot Bay, Frenchman Bay, Cobscook Bay, Englishman Bay, and Starboard Cove) (Breton et al., 2018). Their range of observed heterozygosity was estimated from 0.283 to 0.339 . In European sugar kelp populations, genetic diversity has been estimated with the same 12 microsatellite markers 
and reported much higher observed heterozygosity (Nielsen et al., 2016; Paulino et al., 2016). For example, Møller Nielsen et al., (2016) reported that the observed heterozygosity was 0.560. Lower genetic diversity in western North Atlantic benthic taxa relative to Europe has been reported for multiple taxa (Ware and Cunningham 2001) and hypothesized to result from postglacial recolonization from East to West. The purpose of the conStruct model is to raise hypotheses concerning the population history of a species (Bradburd et al. 2018). In the context of these previous observations, we propose two of the layers we found to be distinct colonization events from east to west in the Atlantic, while the third layer derives from the separation of subpopulations due to the Cape Code barrier. Admixture and divergence, we believe, could be the odd geographic pattern of genetic differentiation observed.

Compared with GOM (mean observed heterozygosity $=0.29)$, SNE exhibited modestly lower $(\mathrm{p}-$ value $<0.05$ ) genetic diversity (mean observed heterozygosity $=0.27$ ). This difference could be due to either a lower effective population size in SNE populations at the range limit, or that greater migration to GOM than to SNE occurred during the second re-colonization event. In the future, genome-wide SNP data should be applied to sugar kelp genetic diversity globally. Such information can show whether the SNE population exhibits adaptation to higher water temperatures or is merely bottlenecked. That inference will be important for improving our understanding of how kelp responds to climate change (Hoffman and Sgrò 2011).

\section{Conclusion}

In the Northwest Atlantic, the coastal geography, currents, vicariance events, and genetic drift have led to ecological diversification and separation of Saccharina latissima gene pools in the GOM and SNE subpopulations. Cape Cod was confirmed to be a longstanding biogeographic 
barrier between GOM and SNE sugar kelp, but perhaps not completely impermeable in the recent past. It is notable that despite this deep regional population structure, the genetic variation found within locations accounted for the greatest proportion of the total, indicating abundant local standing diversity for selection to act on. Breeding among samples between these two regions is currently managed and prohibited due to conservation concerns. Our results indicate that these regions might have already exchanged migrants on their own over time. Nonetheless, as in other similar studies including Evankow et al., (2019), our recommendation supports the precautionary principle to only use regional ecotypes for cultivation and to not transport kelp strains across different regions (e.g. between GOM and SNE, in this case). We also reveal a novel SNP association with a morphological trait and additional candidates for selection in sugar kelp. Our study can be used to guide conservation and management decisions as well as future kelp breeding research. 


\section{Acknowledgments}

Funding support from the U.S. Dept. of Energy ARPA-E (DE-AR0000915). We acknowledge Christina Marie Rochus for suggestions on the data analyses.

\section{Author contribution statement}

$\mathrm{XM}$ and SA wrote the manuscript draft. XM and $\mathrm{MH}$ performed the analysis and discussed results together. $\mathrm{XM}, \mathrm{SA}$, and $\mathrm{MH}$ revised the manuscript together. $\mathrm{MPH}$ guided population genetic analyses and edited the manuscript. CY offered guidance on collections and DB, SL and SA collected samples. DB, SL, SA, SU and MM-R phenotyped the samples. KRR guided analyses, provided computational resources and edited the manuscript; SL, CY and J-LJ led the project and edited the manuscript.

\section{Competing Interests}

The authors of this study declare that there is no conflict of interest in this study.

\section{Data Availability}

Supplemental data is available online

\section{References}

Augyte, S., Yarish, C., Redmond, S. and Kim, J. K. (2017). Cultivation of a morphologically distinct strain of the sugar kelp, Saccharina latissima forma angustissima, from coastal 
Maine, USA, with implications for ecosystem services. J. Appl. Phycol. 29, 1967-1976.

Augyte, S., Lewis, L., Lin, S., Neefus, C. D. and Yarish, C. (2018). Speciation in the exposed intertidal zone: the case of Saccharina angustissima comb. nov . \& stat. nov .

(Laminariales, Phaeophyceae). Phycologia 57, 100-112.

Barrento, S., Camus, C., Sousa-Pinto, I., and Buschmann, A.H. (2016) Germplasm banking of the giant kelp: our biological insurance in a changing environment, Algal Res. 13, 134140. https://doi.org/10.1016/j.algal.2015.11.024.

Bartsch, I. Wiencke, C., Bischof, K., Buchholz, C. M., Buck, B. H., Eggert, A., Feuerpfeil, P., Hanelt, D., Jacobsen, S., Karez, R., Karsten, U., Molis, M., Roleda, M. Y., Schubert, H., Schumann, R., Valentin, K., Weinberger, F., and Wiese, J. (2008). The genus Laminaria sensu lato: recent insights and developments. European Journal of Phycology 43, 1-86. doi:10.1080/09670260701711376

Beerli, P. (200). How to use migrate or why are markov chain monte carlo programs difficult to use? In G. Bertorelle, M. W. Bruford, H. C. Hauffe, A. Rizzoli, and C. Vernesi, editors, Population Genetics for Animal Conservation, volume 17 of Conservation Biology, pages 42-79. Cambridge University Press, Cambridge UK.

Bjerregaard, R., Valderrama, D., Sims, N., Radulovich, R., Diana, J., Capron, M., Forster, J., Gaudey, C., Yarish, C., Hopkins, K., Rust, M., and McKinnie, C. (2016). Seaweed Aquaculture for Food Security, Income Generation and Environmental Health Security in Tropical Developing Countries. World Bank Group Environmental and National Resources.

Breton, T. S., Nettleton, J. C., O’Connell, B. and Bertocci, M. (2018). Fine-scale population genetic structure of sugar kelp, Saccharina latissima (Laminariales, Phaeophyceae), in 
eastern Maine, USA. Phycologia 57, 32-40. doi:10.2216/17-72.1

Bolton, J.J. (2010). The biogeography of kelps (Laminariales, Phaeophyceae): a global analysis with new insights from recent advances in molecular phylogenetics. Helgoland Marine Research 64, 263-279.

Bonhomme, M., Chevalet, C., Servin, B., Boitard, S., Abdallah, J., Blott, S., and SanCristobal, M. (2010). Detecting selection in population trees: The Lewontin and Krakauer test extended. Genetics. doi:10.1534/genetics.110.117275

Bradburd, GS, Coop, G.M., and Ralph, P.L. (2018). Inferring continuous and discrete population genetic structure across space. Genetics 210, 33-52. doi:1011534/genetics.118.301333

Buschmann, A., Camus, C., Infante, J., Neori, A., Israel, Á., Hernández- González, M.C., Pereda, S.V., Gomez-Pinchetti, J.L., Golberg,A., Tadmor-Shalev, N., and Critchley, A.T. (2017). Seaweed production: overview of the global state of exploitation, farming and emerging research activity. Eur. J. of Phycol. 4, 391-406. doi:10.1080/09670262.2017.1365175

Campbell, I., Macleod, A., Sahlmann, C., Neves, L., Funderud, J. Øverland, M., Hughes, A. D., and Stanley, M. (2019). The environmental risks associated with the development of seaweed farming in Europe - prioritizing key knowledge gaps. Front. Mar. Sci. 6, 1-22. 10.3389/fmars.2019.00107

Dayton, P. K. (1985). Ecology of kelp communities. Annu. Rev. Ecol. Syst. 16, 215-245.

Dixon, P. (2003). VEGAN, a package of R functions for community ecology. Journal of Vegetation Science. doi:10.1111/j.1654-1103.2003.tb02228.x

Durrant, H. M. S., Barrett, N. S., Edgar, G. J., Coleman, M. A. and Burridge, C. P. (2018). 
Seascape habitat patchiness and hydrodynamics explain genetic structuring of kelp populations. Mar. Ecol. Prog. Ser. 587, 81-92.

Egan, B., and Yarish, C. (1988). The distribution of the genus Laminaria (Phaeophyta) at its southern limit in the Western Atlantic Ocean. Bot. Mar. 31, 155-161.

Efird, T. P., and Konar, B. (2014). Habitat characteristics can influence fish assemblages in high latitude kelp forests. Environ. Biol. Fishes 97, 1253-1263.

Elshire, R. J., Glaubitz, J. C., Sun, Q., Poland, J. A., Kawamoto, K., Buckler, E. S., and Mitchell, S. E. (2011). A robust, simple genotyping-by-sequencing (GBS) approach for high diversity species. PLoS One 6, e19379.

Endelman, J. B. (2011). Ridge regression and other kernels for genomic selection with R package rrBLUP. Plant Genome J. 4, 250.

Excoffier, L., Smouse, P. E. and Quattro, J. M. (1992). Analysis of molecular variance inferred from metric distances among DNA haplotypes: application to human mitochondrial DNA restriction data. Genetics.

Falkenberg, L. J., Russell, B. D. and Connell, S. D. (2012). Stability of strong species interactions resist the synergistic effects of local and global pollution in kelp forests. PLoS One. doi:10.1371/journal.pone.0033841

Fischer, M. C., Rellstab, C., Leuzinger, M., et al. (2017). Estimating genomic diversity and population differentiation - an empirical comparison of microsatellite and SNP variation in Arabidopsis halleri. BMC Genomics 18, 1-15.

Frichot, E., and François, O. (2015). LEA: An R package for landscape and ecological association studies. Methods Ecol. Evol. 6, 925-929.

Grebe, G., Byron, C. J., St. Gelais, A., Kotowicz, D. M., and Olson, T. K. (2019). An 
ecosystem approach to kelp aquaculture in the Americas and Europe. Aqua. Rep. 15, 100215. doi: 10.1016/j.aqrep.2019.100215

Goecke, F., Klemetsdal, G., and Åshild, E. (2020). Cultivar development of kelps for commercial cultivation - past lessons and future prospects. Frontiers in Marine Science. 10.3389/fmars.2020.00110

Hoffmann, A. J., and Santelices, B. (1991). Banks of algal microscopic forms: hypotheses on their functioning and comparisons with seed banks. Mar. Ecol. Prog. Ser. 79, 185-194.

Hoffmann, A. A. and Sgrò, C. M. (2011). Climate change and evolutionary adaptation. Nature $470,479-485$.

Hwang, E.K., Yotsukura, N., Pang, S.J., Su, L., and Shan., T.F. (2019). Seaweed breeding programs and progress in eastern Asian countries. Phycologia 58, 484-495.

Jaccoud, D., Peng, K., Feinstein, D., and Kilian, A. (2001). Diversity arrays: a solid state technology for sequence information independent genotyping. Nucleic Acids Res. 29, e25.

Jombart, T. (2008). Adegenet: A R package for the multivariate analysis of genetic markers. Bioinformatics . doi:10.1093/bioinformatics/btn129

Kamvar, Z. N., Brooks, J. C. and Grünwald, N. J. (2015). Novel R tools for analysis of genome-wide population genetic data with emphasis on clonality. Front. Genet. doi:10.3389/fgene.2015.00208

Kilian, A., Wenzl, P., Huttner, E., Carling, J., Xia, L., et al. (2012). Diversity arrays technology: A generic genome profiling technology on open platforms. Methods Mol. Biol. 888, 67-89.

Kim, J.K., Stekoll, M. and Yarish, C. (2019). Opportunities, challenges, and future directions 
of open-water seaweed aquaculture in the United States. Phycologia. 58, 446-461.

$10.1080 / 00318884.2019 .1625611$

Lipka, A. E., Tian, F., Wang, Q., Peiffer, J., et al. (2012). GAPIT: Genome association and prediction integrated tool. Bioinformatics 28, 2397-2399.

Liu, X., Huang, M., Fan, B., Buckler, E. S. and Zhang, Z. (2016). Iterative Usage of Fixed and Random Effect Models for Powerful and Efficient Genome-Wide Association Studies. PLoS Genet. doi:10.1371/journal.pgen.1005767

Maggs, C. A., Castilho, R., Foltz, D., Henzler, C., et al. (2008). Evaluating signatures of glacial refugia for north atlantic benthic marine taxa. in Ecology 89, S108-S122. doi:10.1890/08-0257.1

Mathieson, A. C., Hehre, E. J., Dawes, C. J. and Neefus, C. D. (2008). An historical comparison of seaweed populations from Casco Bay, Maine. Rhodora 110, 1-102.

Mathieson, A. C. and Dawes, C. J. (2017). Seaweeds of the Northwest Atlantic. University of Massachusetts Press, Amherst, MA.

Møller Nielsen, M. et al. (2016). Genetic diversity of Saccharina latissima (Phaeophyceae) along a salinity gradient in the North Sea-Baltic Sea transition zone. J. Phycol. 52, 523531.

Neiva, J., Paulino, C., Nielsen, M.M., et al. (2018). Glacial vicariance drives phylogeographic diversification in the amphi-boreal kelp Saccharina latissima. Sci. Rep. 8, 1112. doi:10.1038/s41598-018-19620-7

Nielsen, M. M., Kumar, J. P., Soler-Vila, A., Johnson, M. P. and Bruhn, A. (2016). Early stage growth responses of Saccharina latissima spores and gametophytes. Part 1: inclusion of different phosphorus regimes. J. Appl. Phycol. doi:10.1007/s10811-015- 
$0547-\mathrm{z}$

Paine, R. T. (1979). Disaster, catastrophe, and local persistence of the sea palm Postelsia palmaeformis. Science (80-. ). 205, 685-687.

Pappalardo, P., Pringle, J. M., Wares, J. P. and Byers, J. E. (2015). The location, strength, and mechanisms behind marine biogeographic boundaries of the east coast of North America. Ecography (Cop.). doi:10.1111/ecog.01135

Paradis, E., Claude, J. and Strimmer, K. (2004). APE: Analyses of phylogenetics and evolution in R language. Bioinformatics 20, 289-290.

Paulino, C., Neiva, J., Coelho, N. C., et al. (2016). Characterization of 12 polymorphic microsatellite markers in the sugar kelp Saccharina latissima. J. Appl. Phycol. 28, 30713074. doi:10.1007/s10811-016-0811-X

Pembleton, L. W., Cogan, N. O. I. and Forster, J. W. (2013). StAMPP: An R package for calculation of genetic differentiation and structure of mixed-ploidy level populations. Mol. Ecol. Resour. doi:10.1111/1755-0998.12129

Reusch, T. B. H., Ehlers, A., Hämmerli, A. and Worm, B. (2005). Ecosystem recovery after climatic extremes enhanced by genotypic diversity. Proc. Natl. Acad. Sci. U. S. A. 102, 2826-2831.

Richard, G. F., Kerrest, A. and Dujon, B. (2008). Comparative genomics and molecular dynamics of DNA repeats in eukaryotes. Microbiol. Mol. Biol. Rev. 72, 686-727.

Starko, S., Soto Gomez, M., Darby, H., Demes, K.W., Kawai, H., Yotsukura, N., Lindstrom, S. C., Keeling, P. J., Graham, S.W., and Martone, P.T. (2019). A comprehensive kelp phylogeny sheds light on the evolution of an ecosystem. Mol. Phylo. Evol. 136, 138-150.

Trebilco, R., Dulvy, N. K., Stewart, H. and Salomon, A. K. (2015). The role of habitat 
complexity in shaping the size structure of a temperate reef fish community. Mar. Ecol. Prog. Ser. 532, 197-211.

Valero, M. et al. (2011). Using genetic tools for sustainable management of kelps: a literature review and the example of Laminaria digitata. Cah. Biol. Mar. 52, 467-483.

Vos, P., Hogers, R., Bleeker, M., Reijans, M., et al. (1995). AFLP: A new technique for DNA fingerprinting. Nucleic Acids Res. doi:10.1093/nar/23.21.4407

Wade, R., Augyte, S., Harden, M., Nuzhdin, S., Yarish, C. and Alberto, F. (2020) Macroalgal germplasm banking for conservation, food security, and industry. PLOS Biology 18, e3000641. doi: 10.1371/journal.pbio.3000641

Wang, X., Chen, Z., Li, Q., et al. (2018). High-density SNP-based QTL mapping and candidate gene screening for yield-related blade length and width in Saccharina japonica (Laminariales, Phaeophyta). Sci. Rep. 8, 13591.

Wares, J. P. and Cunningham, C. W. (2001). Phylogeography and historical ecology of the North Atlantic intertidal. Evolution (N. Y). 55, 2455-2469.

Wright, S. (1931). Isolation by distance. Genetics 16, 97-159.

Yang, R. C. (2006). Estimating hierarchical f-statistics. Evolution (N. Y). doi:10.2307/2411227

Zhang, N. Zhang, L., Tao, Y. et al. (2015). Construction of a high density SNP linkage map of kelp (Saccharina japonica) by sequencing Taq I site associated DNA and mapping of a sex determining locus. BMC Genomics 16, 189. doi:10.1186/s12864-015-1371-1

Zhang, J., Wang, X., Yao, J., Li, Q., Liu, F., Yotsukura, N., Krupnova, T. N., Duan, D. (2017) Effect of domestication on the genetic diversity and structure of Saccharina japonica populations in China. Sci. Rep. 4, 1-11. doi:10.1038/srep42158 


\section{Tables}

Table 1. Location, sample size and sequence diversity for sampling locations.

\begin{tabular}{|c|c|c|c|c|c|c|c|c|c|}
\hline \multirow{2}{*}{$\underset{1}{\text { Region }}$} & \multicolumn{3}{|c|}{ Location } & \multicolumn{3}{|c|}{ Sample size ${ }^{4}$} & \multicolumn{3}{|c|}{$\begin{array}{l}\text { Sequence } \\
\text { diversity }^{5}\end{array}$} \\
\hline & Location $^{2}$ & Latitude & Longitude & $\begin{array}{c}\text { Phenotype } \\
\text { d }\end{array}$ & $\begin{array}{c}\text { Genotype } \\
\mathrm{d}\end{array}$ & $\begin{array}{l}\text { Phenotype } \\
\mathrm{d} \text { and } \\
\text { Genotyped }\end{array}$ & Ho & $\mathrm{He}$ & $\mathrm{F}_{\mathrm{IS}}{ }^{6}$ \\
\hline \multirow{12}{*}{ GOM } & Lubec Dock, ME & 44.86 & -66.98 & 9 & 8 & 8 & $\begin{array}{c}0.3 \\
1\end{array}$ & $\begin{array}{c}0.2 \\
9\end{array}$ & 0.09 \\
\hline & Lubec Light, ME & 44.84 & -66.98 & 3 & 7 & 1 & $\begin{array}{c}0.3 \\
2\end{array}$ & $\begin{array}{c}0.2 \\
9\end{array}$ & 0.05 \\
\hline & $\begin{array}{c}\text { Downeast Institute, } \\
\text { ME }\end{array}$ & 44.48 & -67.60 & 9 & 9 & 9 & $\begin{array}{c}0.3 \\
2\end{array}$ & $\begin{array}{c}0.3 \\
1\end{array}$ & - \\
\hline & $\begin{array}{l}\text { Mount Desert } \\
\text { Rock, ME }\end{array}$ & 43.97 & -68.13 & 5 & 5 & 5 & $\begin{array}{c}0.2 \\
8\end{array}$ & $\begin{array}{c}0.2 \\
6\end{array}$ & $-\overline{0}$ \\
\hline & Orr's Island, ME & 43.80 & -69.95 & 12 & 10 & 8 & $\begin{array}{c}0.3 \\
1\end{array}$ & $\begin{array}{c}0.3 \\
1\end{array}$ & 0 \\
\hline & $\begin{array}{c}\text { Giant's Staircase }^{3} \text {, } \\
\text { ME }\end{array}$ & 43.72 & -69.99 & 12 & 17 & 12 & $\begin{array}{c}0.2 \\
8\end{array}$ & $\begin{array}{c}0.2 \\
6\end{array}$ & 0.02 \\
\hline & Nubble Light, ME & 43.17 & -70.59 & 14 & 12 & 12 & $\begin{array}{c}0.3 \\
0\end{array}$ & $\begin{array}{c}0.2 \\
9\end{array}$ & $-\overline{0}$ \\
\hline & Fort Stark, NH & 43.06 & -70.71 & 14 & 12 & 11 & $\begin{array}{c}0.3 \\
2\end{array}$ & $\begin{array}{c}0.3 \\
0\end{array}$ & - \\
\hline & Newcastle, $\mathrm{NH}$ & 43.06 & -70.73 & 12 & 11 & 10 & $\begin{array}{c}0.3 \\
2\end{array}$ & $\begin{array}{c}0.3 \\
1\end{array}$ & $-\overline{0}$ \\
\hline & Isles of Shoals, NH & 42.99 & -70.62 & 10 & 10 & 10 & $\begin{array}{c}0.3 \\
1\end{array}$ & $\begin{array}{c}0.2 \\
9\end{array}$ & $\overline{-}$ \\
\hline & $\begin{array}{l}\text { Cape Cod Canal, } \\
\text { MA }\end{array}$ & 41.77 & -70.50 & 17 & 12 & 12 & $\begin{array}{c}0.3 \\
1\end{array}$ & $\begin{array}{c}0.3 \\
0\end{array}$ & $-\overline{0}$ \\
\hline & Fort Wetherill, RI & 41.48 & -71.36 & 13 & 12 & 12 & $\begin{array}{c}0.2 \\
8\end{array}$ & $\begin{array}{c}0.2 \\
8\end{array}$ & 0 \\
\hline \multirow{3}{*}{ SNE } & Pine Island, CT & 41.31 & -72.06 & 2 & 3 & 1 & $\begin{array}{c}0.3 \\
0\end{array}$ & $\begin{array}{c}0.2 \\
8\end{array}$ & 0.01 \\
\hline & Black Ledge, CT & 41.31 & -72.07 & 31 & 12 & 12 & $\begin{array}{c}0.2 \\
9\end{array}$ & $\begin{array}{c}0.2 \\
7\end{array}$ & 0. \\
\hline & Fisher's Island, NY & 41.28 & -71.93 & 2 & 9 & 2 & $\begin{array}{c}0.2 \\
7\end{array}$ & $\begin{array}{c}0.2 \\
7\end{array}$ & $0 . \overline{04}$ \\
\hline
\end{tabular}

${ }^{\mathrm{T}} \mathrm{GOM}=$ Gulf of Maine; SNE $=$ Southern New England.

${ }^{2} \mathrm{ME}=$ Maine; $\mathrm{NH}=$ New Hampshire; $\mathrm{MA}=$ Massachusetts; $\mathrm{RI}$ = Rhode Island CT = Connecticut NY = New York.

${ }^{3}$ Represents Saccharina angustissima populations, all remaining samples were from Saccharina latissima.

${ }^{4}$ Phenotyped: Number of samples which have been phenotyped; Genotyped: Number of samples which have been genotyped; Phenotyped and Genotyped: Number of samples which have been both phenotyped and genotyped.

${ }^{5} \mathrm{H}_{\mathrm{O}}=$ Observed heterozygosity; $\mathrm{H}_{\mathrm{E}}=$ expected heterozygosity;

${ }^{6} \mathrm{~F}_{\mathrm{IS}}=$ inbreeding coefficient $\left(\mathrm{F}_{\mathrm{IS}}\right)$ which was calculated as $\left(\mathrm{H}_{\mathrm{E}^{-}} \mathrm{H}_{\mathrm{O}}\right) / \mathrm{H}_{\mathrm{E}}$. All $\mathrm{F}_{\mathrm{IS}}$ values are significantly $(\mathrm{P}=0.05)$ differently from 0 except for Orr's Island, ME and Fort Wetherill, RI 
Table 2. Analysis of molecular variance for sugar kelp in Northwest Atlantic using genome-wide single nucleotide polymorphisms data.

\begin{tabular}{llcc}
\hline Scenario & Source of variation & Variance & Percentage (\%) \\
All locations & Between regions & 349.55 & 29.26 \\
& Among locations within region & 171.97 & 14.39 \\
& Within location & 673.25 & 56.35 \\
$\mathrm{GOM}^{1}$ & Among locations within region & 202.62 & 23.01 \\
& Within location & 678.11 & 76.99 \\
$\mathrm{SNE}^{2}$ & Among locations within region & 47.98 & 6.80 \\
& Within location & 657.80 & 93.20 \\
\hline
\end{tabular}

${ }^{1} \mathrm{GOM}=$ Gulf of Maine;

${ }^{2} \mathrm{SNE}=$ Southern New England. 


\section{Figure Legends}

Figure 1. Collection locations of 15 subtidal populations of Saccharina latissima and Saccharina angustissima used in this study.

Figure 2. The radar plots for the phenotypic mean \pm standard error (darker shading) in 15 sampling locations. The maximum value for the axis for each trait were as follows; 280.0 $\mathrm{cm}$ for blade length, $30.0 \mathrm{~cm}$ for blade width at $10 \mathrm{~cm}, 50.0 \mathrm{~cm}$ blade width at widest, 3.0 $\mathrm{mm}$ for blade thickness, $160.0 \mathrm{~cm}$ for stipe length, and $21 \mathrm{~mm}$ for stipe diameter.

Figure 3. Phenotypic correlations among six morphological traits. The color gradient is shown at the bottom with red representing a negative correlation and blue representing a positive correlation. Non-significant $(\mathrm{P}$-value $>0.05$ ) correlations were marked with black crosses.

Figure 4. Heat map showing pairwise $\mathrm{F}_{\mathrm{ST}}$ values with hierarchical clustering. Insert graph on the top left is a histogram showing the frequency spectrum of pairwise $F_{S T}$ values.

Figure 5. Principal coordinate analysis (PCoA). Samples are labeled according to their collection locations. The two PCs that explain most of the variation are shown in the plots. (A.) PCoA of 149 samples from all 15 locations; (B.) PCoA of 113 samples from GOM (Gulf of Maine) only.

Figure 6. Admixture proportions estimated for the 149 kelp samples for $\mathrm{K}=5$ (left). Admixture proportions are shown as pie plot at their approximate geographic locations (right).

Figure 7. Mantel tests for correlation between genetic distance (y-axis) and geographic distance in kilometers (x-axis) in the Gulf of Maine and Southern New England. Regression lines are drawn for the Gulf of Maine (blue) and Southern New England (red).

Figure 8. Genome-wide FLK test statistics and simulated 0.995 and 0.975 quantiles. The $\mathrm{x}$-axis is the SNP heterozygosity, and the y-axis is the FLK statistic. The solid line indicates the significance threshold. Significant SNP outliers are highlighted with red 
color above the solid line, consistent with among-population differentiation above that expected from genetic drift alone.

\section{Figures}

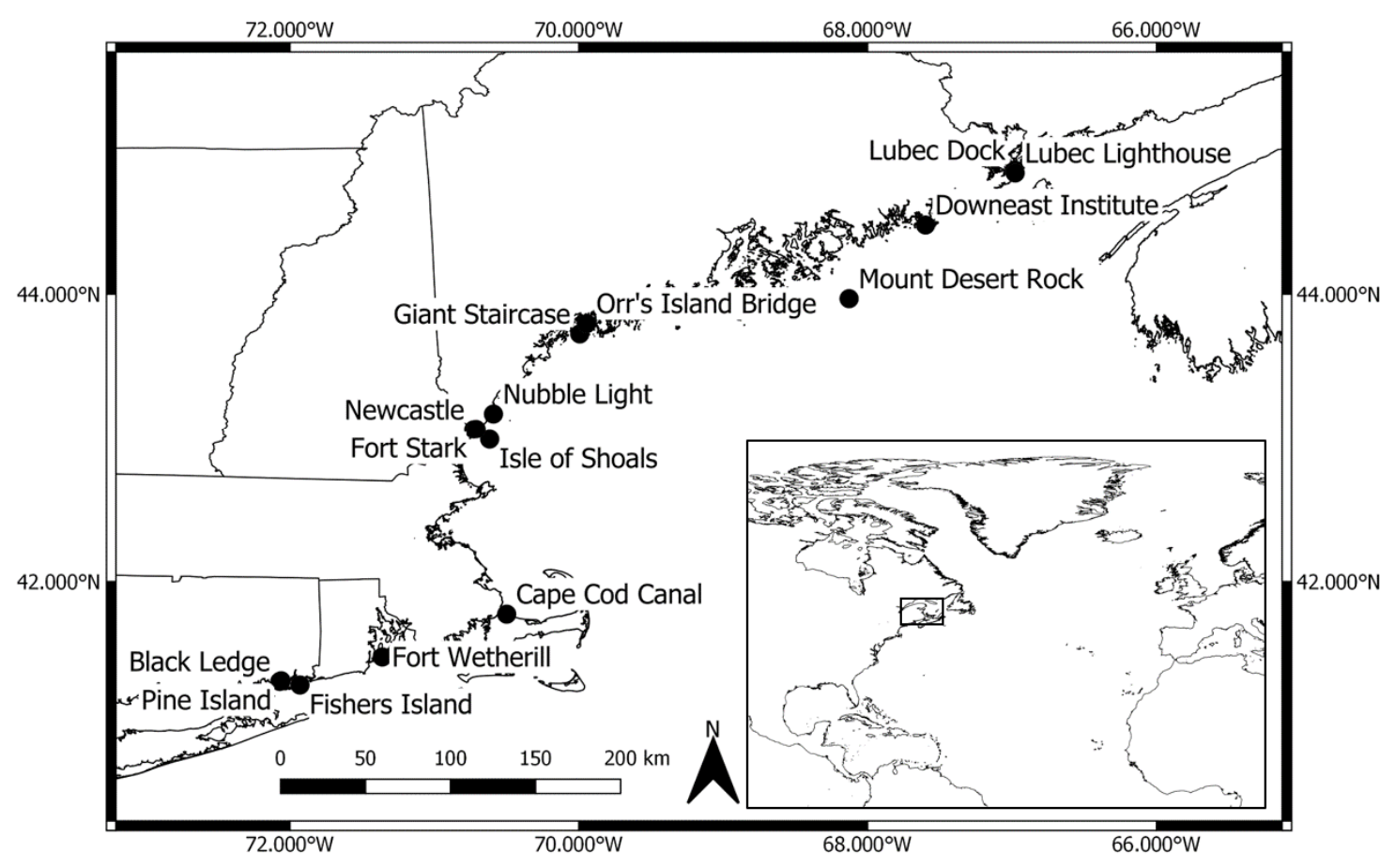

Figure 1 
bioRxiv preprint doi: https://doi.org/10.1101/2020.04.21.050930; this version posted April 23, 2020. The copyright holder for this preprint (which was not certified by peer review) is the author/funder, who has granted bioRxiv a license to display the preprint in perpetuity. It is made available under aCC-BY-NC 4.0 International license.

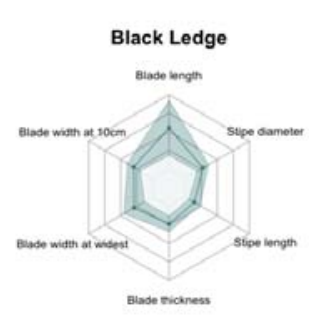

Fort Wetherill

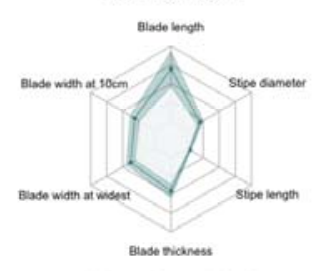

Mount Deset Rock

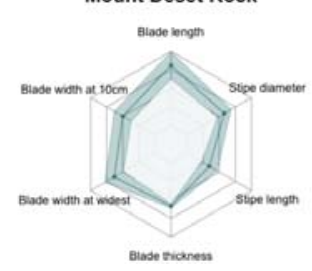

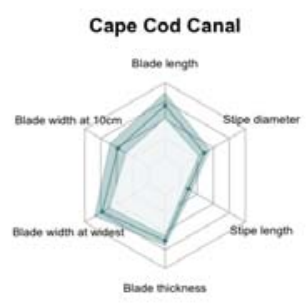

Giant Staircase

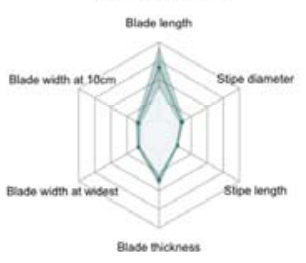

Newcastle

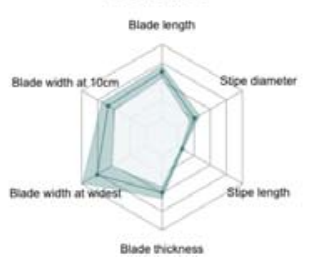

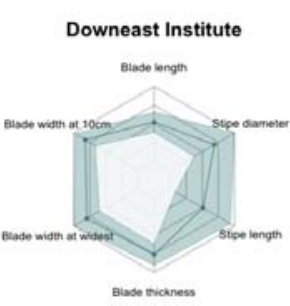

Isle of Shoals

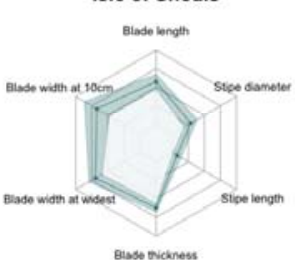

Nubble Light

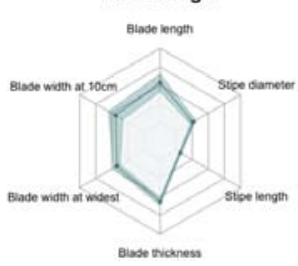

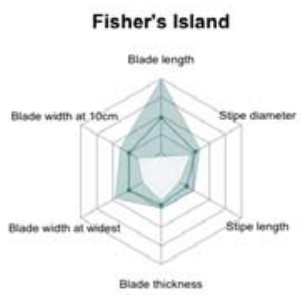

Lubec Dock

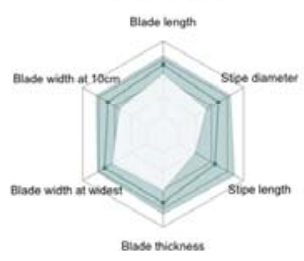

Orr's Island

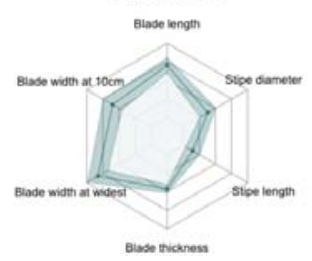

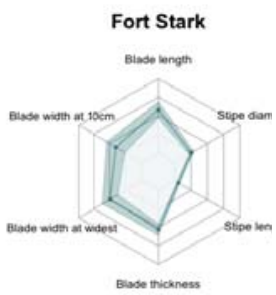

Lubec Light

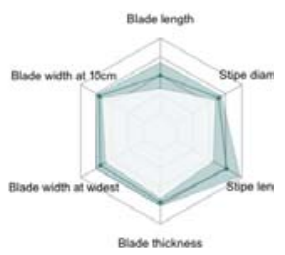

Pine Island

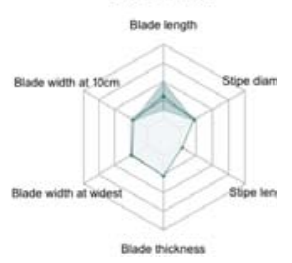

Figure 2 
bioRxiv preprint doi: https://doi.org/10.1101/2020.04.21.050930; this version posted April 23, 2020. The copyright holder for this preprint (which was not certified by peer review) is the author/funder, who has granted bioRxiv a license to display the preprint in perpetuity. It is made available under aCC-BY-NC 4.0 International license.

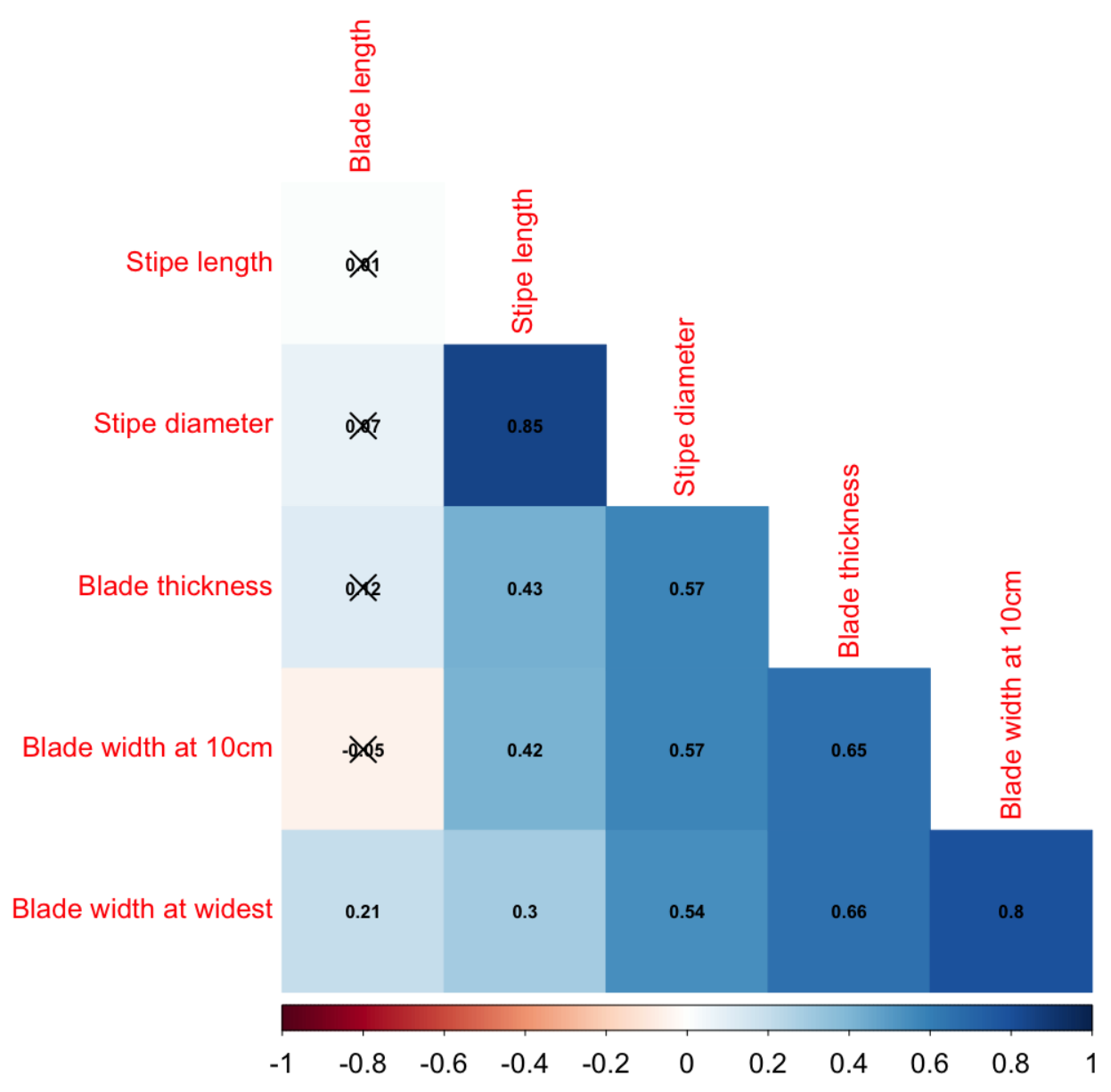

Figure 3 

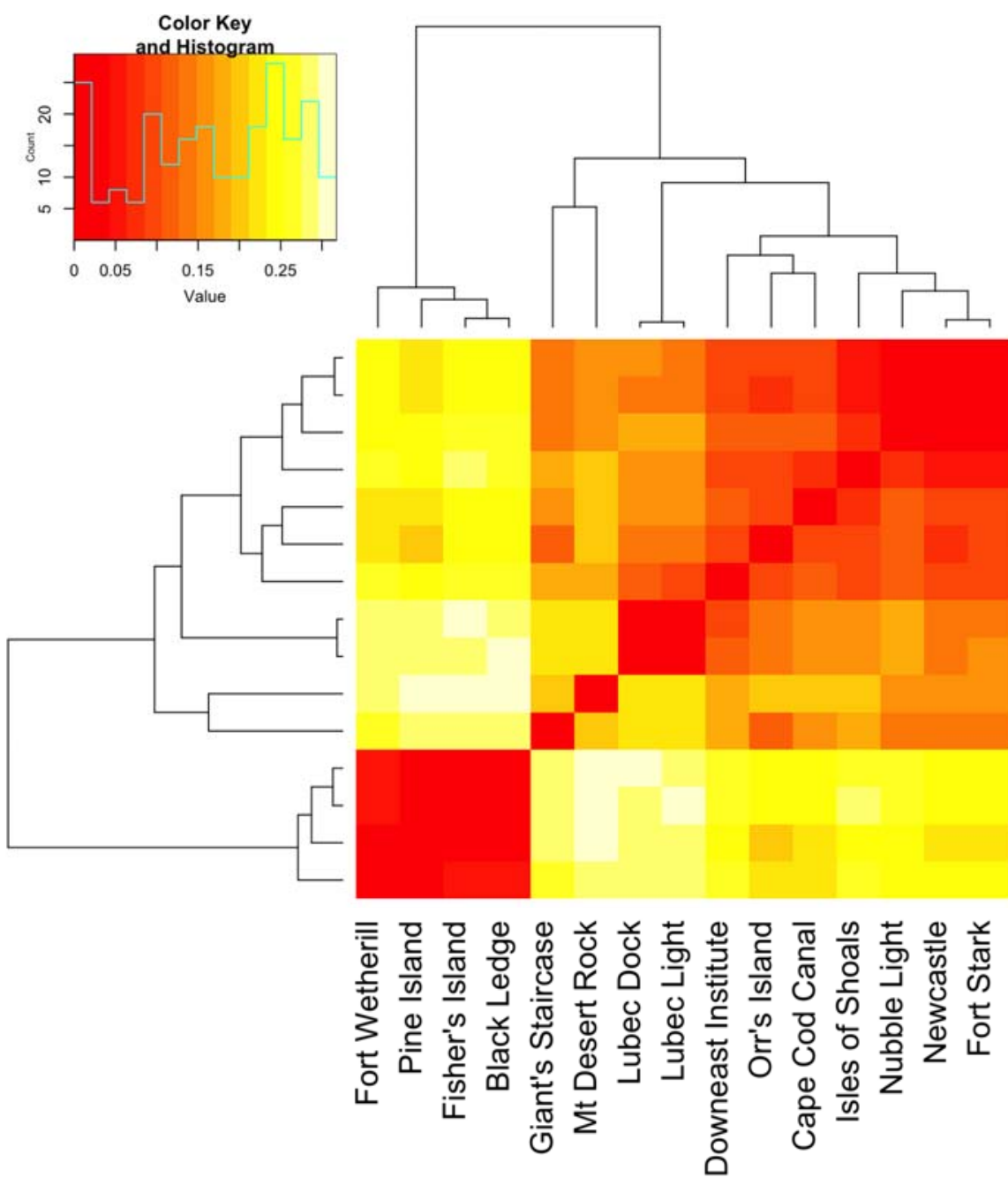

Fort Stark

Newcastle

Nubble Light

Isles of Shoals

Cape Cod Canal

Orr's Island

Downeast Institute

Lubec Light

Lubec Dock

Mt Desert Rock

Giant's Staircase

Black Ledge

Fisher's Island

Pine Island

Fort Wetherill

Figure 4 
bioRxiv preprint doi: https://doi.org/10.1101/2020.04.21.050930; this version posted April 23, 2020. The copyright holder for this preprint (which

was not certified by peer review) is the author/funder, who has granted bioRxiv a license to display the preprint in perpetuity. It is made available under aCC-BY-NC 4.0 International license.

A.

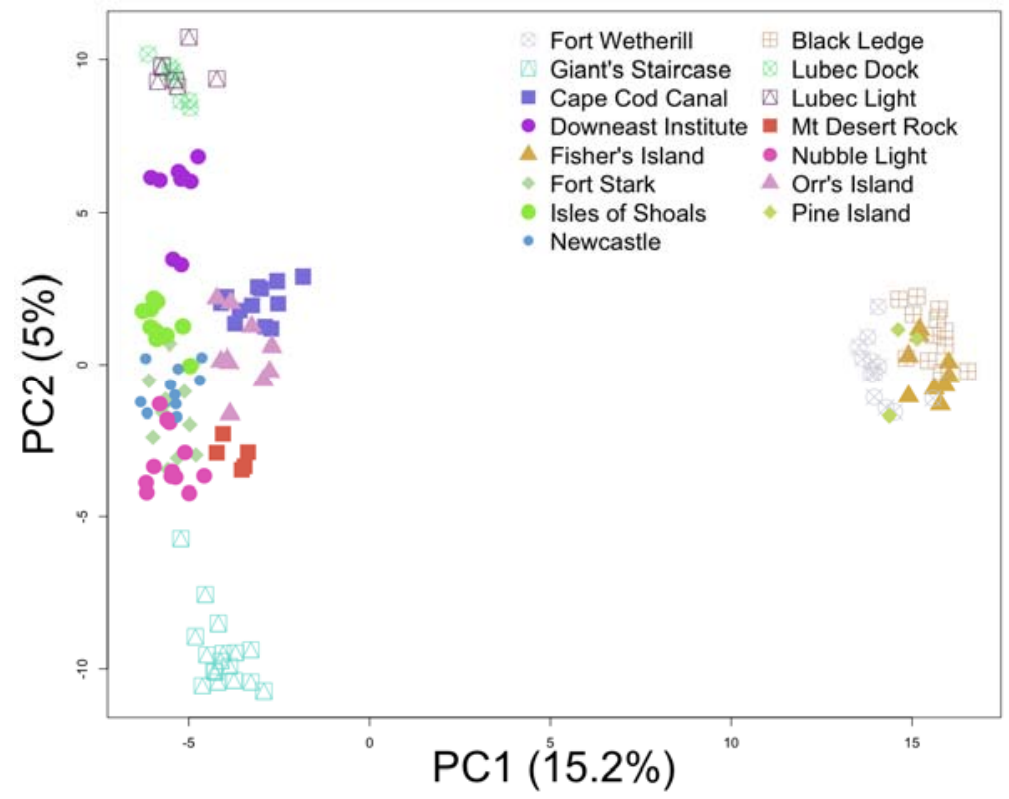

B.

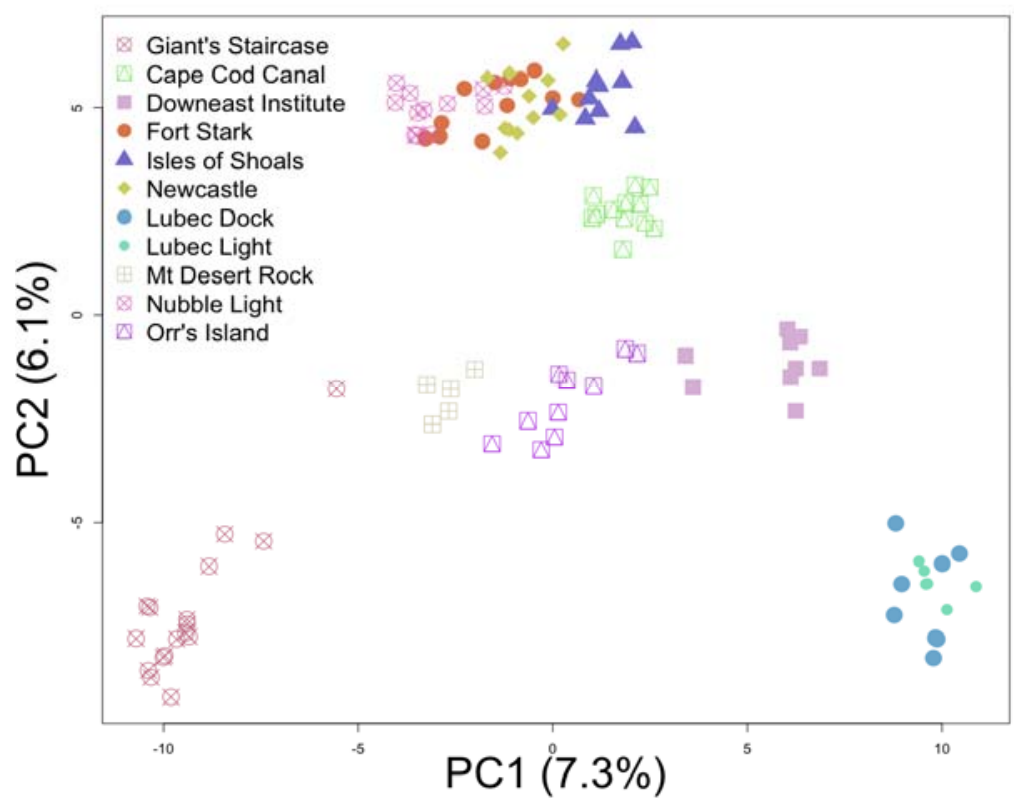

Figure 5 
bioRxiv preprint doi: https://doi.org/10.1101/2020.04.21.050930; this version posted April 23, 2020. The copyright holder for this preprint (which was not certified by peer review) is the author/funder, who has granted bioRxiv a license to display the preprint in perpetuity. It is made available under aCC-BY-NC 4.0 International license.

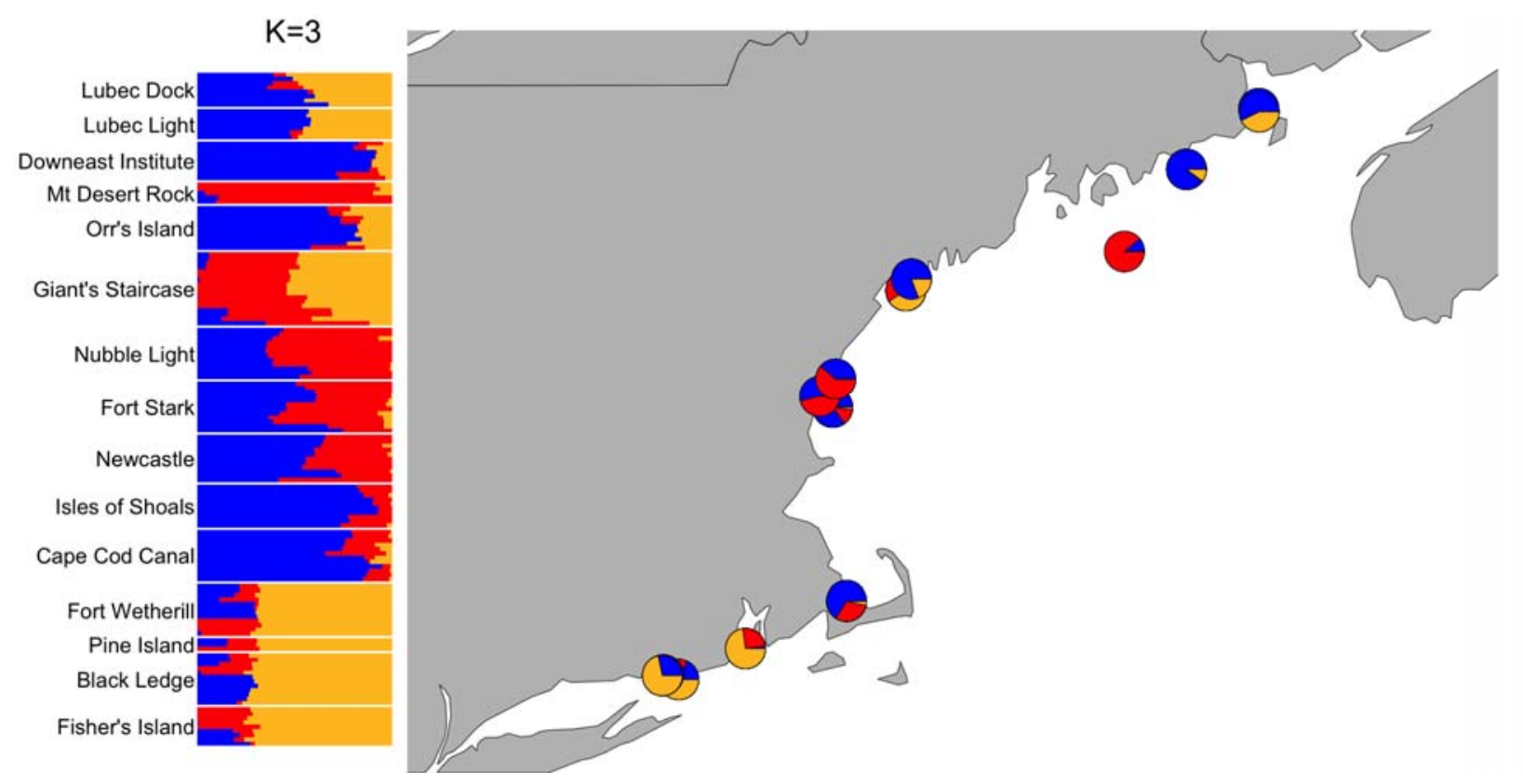

Figure 6 
bioRxiv preprint doi: https://doi.org/10.1101/2020.04.21.050930; this version posted April 23, 2020. The copyright holder for this preprint (which was not certified by peer review) is the author/funder, who has granted bioRxiv a license to display the preprint in perpetuity. It is made available under aCC-BY-NC 4.0 International license.

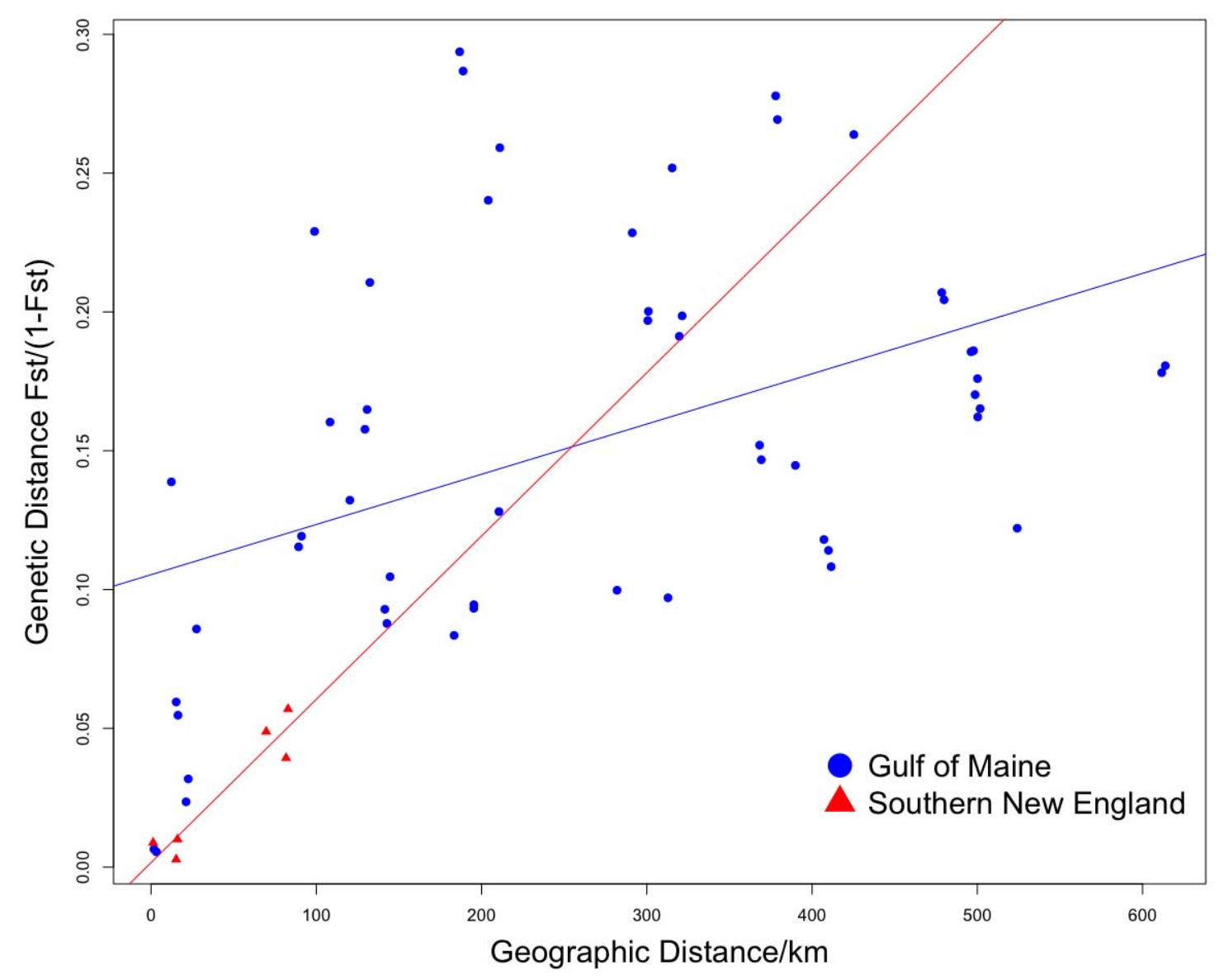

Figure 7 
bioRxiv preprint doi: https://doi.org/10.1101/2020.04.21.050930; this version posted April 23, 2020. The copyright holder for this preprint (which was not certified by peer review) is the author/funder, who has granted bioRxiv a license to display the preprint in perpetuity. It is made available under aCC-BY-NC 4.0 International license.

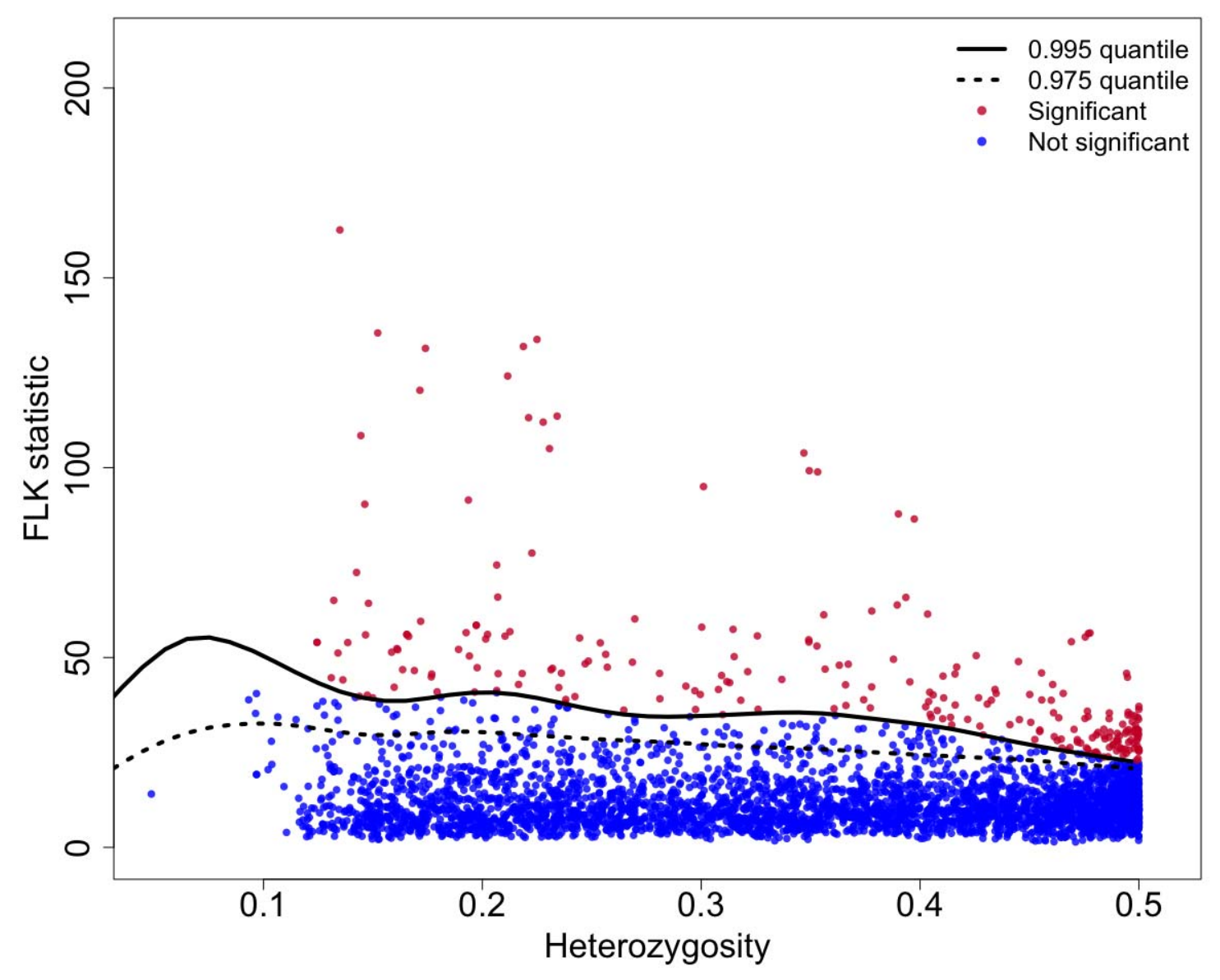

Figure 8 